\title{
Bosque, fotografía y exposición La construcción visual de la Amazonía a través de los clichés de Charles Kroehle y el álbum República peruana 1900
}

\section{Forest, photography and exhibition: visual construction of the Amazon through Charles Kroehle's negative photographic images and the album República Peruana 1900}

Juan Carlos La Serna Salcedo

Universidad de Lima

\section{RESUMEN}

Entre 1888 y 1891, los fotógrafos alemanes Kroehle y Huebner iniciaron una travesía al interior de la selva amazónica que, con el paso del tiempo, ha devenido en épica. Durante su recorrido, realizaron una serie de fotografías del paisaje y la población selváticos, generando una colección de más de doscientas imágenes que terminó convertida en un referente esencial para la construcción visual de la Amazonía. Uno de los principales espacios donde estos clichés fueron expuestos y consumidos por un público global fue en el álbum República peruana 1900, documento elaborado para ser exhibido en la Exposición Universal de París, celebrada en 1900. El objeto del siguiente texto es reflexionar acerca del trabajo fotográfico de Charles Kroehle en nuestro país, destacando la importancia que sus imágenes tuvieron para la construcción de los imaginarios nacionales y las narrativas científicas globales sobre el oriente peruano.

Palabras clave:

Amazonía, fotografía, colecciones, exposición, imaginarios, Charles Kroehle, álbum República peruana 1900

\section{ABSTRACT}

Between the years 1888 and 1891, German photographers Kroehle and Huebner began a journey into the Amazon rainforest that, with the passage of time, has become epic. During their trip, they took a series of photographs of the rainforest landscape and population, generating a collection of more than 200 images that became an essential reference for the visual construction of the Amazon. One of the main spaces in which these negative photographic images were presented and used by a "global" audience was the album República peruana 1900, a document prepared to be displayed at the Universal Exhibition of Paris held in 1900. The purpose of the following text is to reflect on the photographic work of Charles Kroehle in our country, highlighting the importance of his images for the construction of national imaginaries and global scientific narratives about eastern Peru.

\section{Keywords:}

Amazon, photography, collections, exhibition, imaginaries, Charles Kroehle, album República peruana 1900 


\section{A manera de introducción}

$\mathrm{H}$ acia mayo de 1888, los fotógrafos Jean Charles Kroehle y George Huebner partieron de Lima hacia el interior del Perú, atravesando la cordillera andina e introduciéndose en la selva amazónica, en un recorrido épico que, desde entonces, no ha dejado de despertar fascinación. Durante su viaje, que duró cerca de tres años -incluyendo una prolongada estancia en la ciudad de lquitos - realizaron una serie de fotografías del paisaje y de la población selváticos, constituyendo una colección de imágenes que terminó convertida en un referente esencial para la construcción visual de la Amazonía, tanto por parte de las élites intelectuales y políticas peruanas, como en los centros científicos norteamericanos y europeos. Desde entonces y hasta nuestros días, sus vistas han circulado en diferentes escenarios, siendo consumidos por un auditorio diverso, a través de distintos formatos como postales, fotograbados en la prensa, publicaciones fotográficas y en diversos escenarios como museos, repositorios científicos y exposiciones públicas. Uno de los principales soportes en los que estas imágenes fueron expuestas y consumidas por un público global fue en el álbum fotográfico República peruana 1900, documento oficial elaborado para ser exhibido en el pabellón nacional durante la Exposición Universal de París, celebrada en 1900, con motivo del advenimiento del siglo xx.

A diferencia de otros países con tradición pictórica romanticista, donde la pintura sirvió como soporte de proyección de imágenes del paisaje y una idea nacional del territorio, en el Perú no se conoce una producción artística decimonónica con estos referentes. En nuestro caso, la fotografía -y las aplicaciones técnicas que permitieron su impresión y expandieron su consumo: la litografía y el fotograbado- fue la herramienta mediante la cual, a partir del último tercio del siglo XIX, algunos artistas y técnicos fotográficos construyeron los primeros registros visuales del interior del país, como parte de los esfuerzos de territorialización, es decir, la apropiación simbólica y material del paisaje desde la mirada de las élites urbanas.

En este sentido, el álbum República peruana 1900 se presenta como el primer esfuerzo por construir la imagen oficial del país, integrando visualmente los diferentes escenarios y habitantes costeños, serranos y selváticos contenidos en el territorio, en un contexto marcado por los discursos de regeneración nacional postbélica y de progreso material, que impulsaron la necesidad de alcanzar, merced al uso de herramientas científicas y tecnológicas como la camera obscura, un control efectivo del espacio y la conversión de una mayoritaria población indígena en ciudadanos de una nación moderna y civilizada'.

\section{Peregrinaciones fotográficas de un alsaciano en el Perú}

Jean Charles Kroehle (conocido como Charles, Carlos y Karl Kroehle o Kröhle) fue un fotógrafo y aventurero alsaciano. Nació en Estrasburgo el 7 de noviembre de 1862 y fue hijo de Jean Kroehle y Maria Zimmermann². Una vez que, tras la guerra franco-prusiana de 1871, el territorio de Alsacia pasó a convertirse en un Reichsland, la familia Kroehle asumió, legalmente, la nacionalidad alemana. Más adelante, ya establecido en París, Charles Kroehle reclamó su reincorporación a la nacionalidad francesa ${ }^{3}$.

Si bien este personaje y su obra fotográfica amazonista han merecido numerosas investigaciones en los últimos años, su historia de vida nos es todavía extraña ${ }^{4}$. Según el obituario publicado en la prensa limeña por el austríaco David Pretzner, Kroehle aprendió el oficio de la fotografía con un tío suyo "uno de los

1 Iniciativa estatal de articulación visual de la nación y su territorialidad que tuvo como antecedente directo el Atlas de Paz Soldán, publicado en 1865, durante al apogeo guanero.

2 Véase Gobé (2015), La Serna y Chaumeil (2016).

3 Tras la guerra franco-prusiana de 1871, las regiones de Alsacia y Lorena fueron anexadas al Imperio alemán y las poblaciones de frontera tuvieron la opción de elegir entre emigrar a Francia o permanecer en el territorio, adquiriendo automáticamente la nacionalidad alemana. Este fue el caso de Charles Kroehle, quien, en mayo de 1885, solicitó al Ministère de la Justice su reincorporación a Francia. Ver "Demande de Réintégration de Jean Charles Kroehle", 19 de mayo de 1885. Carpeta n. 2430 X85 (Caja BB11/1838). El decreto de reintegración está fechado el 4 de agosto de 1885 (Caja BB/34/389). Archives Nationales de France. (Información proporcionada por Pascal Riviale).

4 Por ejemplo, entre los trabajos recientes dedicados a la obra de Kroehle, se cuentan los de Kohl (2015), Gobé (2015), Chaumeil (2014), Flores (2011), La Serna (2011) y Schoepf (2000), así como las exposiciones "George Huebner (1862-1935). Un photographe à Manaus", realizada en el Museo de Etnografía de Ginebra, entre el 2000 y 2001; “D'un regard l'Autre. Photographies xIxe 
más eminentes artistas de París" (Pretzner, 1900). En la solicitud de reincorporación remitida al Ministerio de Justicia, Kroehle señaló su arribo a Francia hacia noviembre de 1884, estableciendo su domicilio en la calle La Chapelle n. ${ }^{\circ} 22$, en París, donde se desempeñaba como "obrero en fotografía".

Al poco tiempo, decide iniciar su aventura sudamericana. Recorre el río Amazonas, desde su desembocadura, en el Brasil, y se instala en el puerto peruano de lquitos (Pretzner, 1990). Durante esta temprana estancia selvática, que podría fecharse entre 1886 y 1888, debió dedicarse a la actividad fotográfica y, probablemente, al comercio o la extracción de la goma. Es posible que en este tiempo haya realizado sus primeras vistas fotográficas de los paisajes y poblaciones del interior del país 5 .

A inicios de 1888, conoce al alemán Georg Huebner, quien hacia esta fecha había arribado a Lima tras una estancia de tres años en lquitos y la selva central (Pozuzo, Chuchurras), donde se dedicó al negocio de la goma6. Este encuentro de intereses por la camera obscura y los recursos del bosque los llevaría a iniciar una aventura fotográfica que duraría hasta 1891. En un texto publicado por Huebner en la prensa alemana, se desprende el interés comercial que tuvo esta empresa y la posibilidad de "ganar consideración" de una serie de actores, políticos, empresariales y académicos, interesados en los territorios amazónicos peruanos:

Mi objetivo era realizar un conjunto de fotografías de regiones que eran parcialmente desconocidas, de los grupos indígenas salvajes que vivían al otro lado de los Andes, y así esperaba ganar consideración de todas las personas que se interesaban por el interior del Perú. (como se citó en Schoepf, 2005, p. 20)

De este modo, en mayo de 1888, los fotógrafos iniciaron su viaje al interior del Perú. Parten de Lima en el Ferrocarril Central, tomando diversas vistas de su paso por Chicla y La Oroya, entre las serranías de Lima y Junín, para luego descender por Huanchón
(Pasco) hacia los valles selváticos de Huancabamba y el Palcazú. Prosiguieron su recorrido por el Pachitea y el Ucayali, hasta llegar a lquitos el 22 de noviembre de 1888 (Flores, 2011).

La decisión de ingresar a la Amazonía por la montaña de Pasco debió ser motivada por la presencia de una colonia de inmigrantes alemanes asentados en los diferentes valles de la región, especialmente en Pozuzo, a quienes podían fotografiar y con quienes los artistas tuvieron una relación previa. Tomando en cuenta que portaban una apreciable cantidad de bultos con sus equipos fotográficos, para el descenso a la selva desde las alturas de Huanchón contrataron los servicios de un arriero, de nombre Hidalgo. Asimismo, compartieron parte del viaje con el cauchero Guillermo Frantzen, quien se dirigía al puerto de lquitos. El viajero Carlos Fry Piérola anota en su diario de viaje el encuentro con "Carlos Kröhle y Jorge Hübner" en Sungaruyacu, en la cuenca del Pachitea, el 18 de agosto de 1888. Mientras que Fry viajaba acompañando una comitiva del conocido cauchero y explorador Carlos Fitzcarrald, que se dirigía al Palcazú, los fotógrafos alemanes iniciaban su descenso con dirección al Amazonas:

\section{Los fotógrafos tomaron vistas de este lugar, pues sus procedimientos en planchas secas y sin el colodium sensible que exige cámara oscura eran apropia- das para el lugar [...] A las diez estuvo de vuelta el señor Fiscarrald [sic] y se procedió al almuerzo tan concurrido, hoy, después de tantos días de soledad; se despidieron los fotógrafos, Hidalgo y Frazen, para continuar su viaje de bajada, que les será muy rápido por la creciente del río. (Fry, 1889, p. 51)}

Permanecieron cerca de medio año en la ciudad de lquitos, capital del negocio de la goma en el Perú, al tiempo que establecieron una casa fotográfica La Fotografía del Amazonas, que tuvo corta duración, probablemente, por el escaso mercado que significaba la población local, compuesta por pequeños comerciantes, aventureros y caucheros de paso. Faltaban todavía algunos años para que la prosperidad del tráfico de la

siècle", organizado en el Museo de quai Branly, en París, entre el 2006 y 2007, en cuya publicación se incluye un cliché de Kroehle \& Huebner como fotografía de portada; "La Amazonía según Charles Kroehle. Fotos y postales de fines del siglo xIx e inicios del xx", organizada por el Centro Cultural Garcilaso de la Vega, en Lima, en el 2010; y "En el País de las Amazonas", por el Centro Cultural Británico, también en Lima, en el 2017, donde aparecen algunos clichés, postales basadas en sus fotografías y algunas apropiaciones artísticas contemporáneas de su obra.

5 Se conoce un álbum con vistas de la ciudad de Lima y haciendas e indígenas de la montaña de Chanchamayo, con clichés fechados entre 1888-1889, que, probablemente, sean de su autoría. Algunas de ellas fueron reproducidas, sin referencias de autoría, en la revista El Perú Ilustrado (La Serna y Chaumeil, 2016).

6 Huebner llegó a lquitos en 1886 y, luego de una estadía en la colonia alemana de Pozuzo, se estableció durante año y medio en la zona de Chuchurras, donde mantuvo relaciones con Guillermo Frantzen, propietario tirolés dedicado al negocio de la goma. Desde allí, partió a Lima hacia 1888. En Huebner, G. (1993). Iquitos und die Kautschuksammler am Amazonenstrom. Globus. Illustrierte Zeitschrift für Länder-und Völkerkunde. Vol. 64, n. 7, 1993, pp. 101-105, 122-127 (tomado de Valentin, 2009, p. 97). 
goma diera nacimiento a las grandes fortunas y los días dorados de esta ciudad.

En junio de 1889, partieron con dirección a Yurimaguas. Continuaron el viaje, con cortas estadías en las poblaciones de Lamas, Moyobamba, Rioja, Tarapoto - donde realizaron exhibiciones públicas con una linterna mágica-, Chachapoyas, subiendo hacia la sierra por Cajamarca, donde se dedicaron a la venta de reproducciones fotográficas (Valentin, 2009). De allí, pasaron hacia la ciudad de Trujillo. En mayo de 1891, Huebner se embarcó hacia Panamá desde el puerto de Pacasmayo, con destino a Europa, mientras que Kroehle retornó a Lima. Nunca más se volverían a encontrar.

Huebner volvió a la Amazonía hacia 1894, realizando una serie de expediciones por el alto Orinoco y Río Branco, en el Brasil. Hacia 1897, se instaló permanentemente en Manaos, la pujante ciudad cauchera del Brasil, donde estableció la Fotografía Alemana y se convirtió en uno de los más destacados fotógrafos locales de primera mitad del siglo $x^{7}$.

Es todavía escasa la información que tenemos para reconstruir la vida de Carlos Kroehle durante la década que permaneció en Lima, luego de la aventura amazónica junto a Huebner. A su retorno a Lima, Kroehle abrió un estudio en la calle Quilca n. 53 (Plazuela de la Salud n. ${ }^{\circ}$ 33, actualmente, Plazuela Helguera ${ }^{8}$, desde donde, además de realizar fotografías de salón, distribuyó sus clichés amazónicos a distintas instituciones estatales, viajeros y coleccionistas nacionales y extranjeros de paso por la ciudad 9 .

La casa Kroehle fue el rendes-vous de todos los aficionados al arte fotográfico, de todos los distinguidos extranjeros que llegaron a estas playas; encargándole copias de las más raras vistas de las regiones fluviales, de las ruinas y monumentos incaicos, en las que abundaban sus colecciones. (Pretzner, 1900)
Así, por ejemplo, en su paso por Lima entre 1891 y 1892, William E. Safford, comisionado por la sección de etnología y antropología de la Exposición Universal de Chicago (1893), recolectó un grupo de fotografías de Kroehle que sirvieron para clasificar los tipos amazónicos peruanos en la exhibición (La Serna y Chaumeil, 2016). Del mismo modo, el geógrafo y fotógrafo norteamericano Frank G. Carpenter detallaba su encuentro con Kroehle hacia 1897, gracias al cual pudo adquirir un grupo de imágenes de sujetos amazónicos que luego incorporó en su obra sobre los países sudamericanos (Carpenter, 1900).

Más adelante, la viajera y científica alemana Therese von Bayern anota su encuentro con Kroehle en Lima, hacia 1898. Además de las descripciones que el fotógrafo le ofreció acerca de su travesía amazónica, pudo hacerse de un conjunto de fotografías y piezas etnográficas asháninkas (atuendos, lanzas y flechas). El libro de Von Bayern (1908) incluye doce fotograbados de indígenas, individuales y grupales, sobre la base de estos clichés ["A partir de una fotografía de Kröhle-Lima"]. Sobre su encuentro con el fotógrafo alsaciano y el uso de sus materiales en su obra, señalaba la autora:

Todas las fotografías de indios fueron tomadas por Kroehle en una expedición que este fotógrafo alemán realizó al este del Perú, tomadas en las mismas residencias de los indios, dándome los detalles de su viaje personalmente cuando me fueron entregados por él en Lima. (Von Bayern, 1908) ${ }^{10}$

Sobre la actividad profesional de Kroehle en la ciudad de Lima, tenemos dos notas periodísticas que dan cuenta de su labor como fotógrafo en eventos organizados por el Club Lima, en las inmediaciones de Magdalena del Mar, donde esta asociación tenía su local y realizaba sus concursos y demás actividades sociales ${ }^{11}$. En el obituario publicado por David Pretzner (1900) se señala que parte de sus ocupaciones consistía en enseñar el arte

7 Huebner volvería unos años después a lquitos, como fotógrafo itinerante, en un viaje que fue especialmente destacado por la prensa local. Véase Anónimo. Fotografía Alemana. El Independiente (Iquitos), 23 de abril de 1898.

8 También se ha anotado su dirección en Matajudíos n. 13 (Riviale y Galinon, 2014).

9 Se conocen fotografías de estudio y vistas de Lima, el Callao y Chorrillos reproducidas por el artista en la década de 1890, con los sellos "Kroehle Fotógrafo", "Carlos Kroehle / Fotógrafo/ Plazuela de la Salud 53" y "South American Photo Co.", y otras con las firmas "Ch. Kroehle", "C. K.", grabadas sobre las imágenes.

10 Existen distintas colecciones fotográficas elaboradas por viajeros, comerciantes y diplomáticos en su paso por el Perú, las que integran los clichés amazónicos de Kroehle \& Huebner. Entre estas, tenemos los álbumes del etnógrafo Max Uhle (hoy en el fondo del Instituto Iberoamericano de Berlín), el legado del explorador M. A. Viellerobe y el álbum de Jean Stroemsdoerfer, cónsul de Alemania y Suiza en Lima, entre 1887 y 1901 (Colección Percy Reinoso, París), y un álbum sobre el Perú, de autoría anónima, elaborado hacia 1892, acopiado en la fototeca del Museo Etnográfico de Hamburgo.

11 El Club Lima era una asociación amateur de práctica de tiro, que inició sus actividades en marzo de 1896. Véase Anónimo. (4 de mayo de 1896). Club Lima. El Comercio [edición de la mañana], p. 2; Anónimo. (25 de mayo de 1896). Club Lima. El Comercio [edición de la mañana], p. 2. Entre los socios del club se encontraba Eduardo Polack, quien a partir de 1901 iniciaría la edición de sus tarjetas postales con vistas del Perú, incluyendo diversos clichés de Carlos Kroehle y de Kroehle \& Huebner. 
fotográfico a jóvenes limeñas de familias acomodadas. Es probable que esta función la realizara en alguno de los colegios privados de señoritas que, para finales del siglo xIX, se habían instalado en la capital ${ }^{12}$.

Diversas fuentes dan cuenta de la fuerte cercanía que el fotógrafo mantenía con la comunidad alemana y filogermánica en la capital, colectividad compuesta por comerciantes, profesionales y científicos. Algunos de ellos son especialmente significativos para la historia de la fotografía y los imaginarios visuales sobre el Perú, como Eduardo Polack, Guillermo Stolte, Carlos Tinning o Max Uhle. Las relaciones de Kroehle y los alemanes de Lima fueron destacadas, no sin condena, por el inmigrante francés Teodoro Ber, quien, luego de su encuentro con Kroehle hacia 1892, resaltó sus carencias económicas, al punto de señalar que su subsistencia dependía de la venta de las reproducciones a diferentes interesados en curiosidades amazónicas:

Desde su arribo a Lima se ha visto obligado a vivir al día de la venta de las reproducciones de sus clichés lo que le ha hecho conocido entre los alemanes que lo rodean y lo tratan como a un compatriota, nacido en Estrasburgo. (Riviale y Galinon, 2014) ${ }^{13}$

En este mismo sentido, en una carta que María Kroehle, hermana del fotógrafo, remite a la dirección del Museo de Etnografía de Berlín, ofreciendo en venta un conjunto de clichés y materiales etnográficos reunidos en Lima por el fotógrafo, se señala explícitamente su muerte en condiciones de miseria (Schoepf, 2005). Al parecer, Kroehle pagó con su vida el atrevimiento de enfrentar el bosque y sus peligros: enfermedades, ataques de los salvajes y mayores privaciones.
Kroehle fallece en Lima, internado en la Maison de Santé, el 7 de diciembre de 1900 (La Serna y Chaumeil, 2016). Tenía 38 años. Al poco tiempo, el fotógrafo Carlos Lara se presentó como su sucesor ante el público limeño adquiriendo, presumiblemente, sus aparatos y parte de sus colecciones fotográficas (Majluf y Wuffarden, 2001). Es probable que, además de Lara, sus negativos pasaran a manos de otros fotógrafos y editores locales.

La historia de su muerte a consecuencia de una herida abierta por una flecha que nunca sanó ha aparecido reiteradamente en los textos que ofrecen alguna información sobre su biografía, hecho que lo convirtió en una especie de leyenda ${ }^{14}$. Así, lo señalaba tempranamente Teodoro Ber cuando lo encuentra en 1892, anotando la peligrosa herida que presentaba al costado del pecho, a causa de un ataque con flechas que sufrió en su travesía ${ }^{15}$.

Una nota periodística reproducida en la prensa norteamericana, comentando la presencia de W. E. Safford en el Perú, daba cuenta de la lesión de Kroehle ocho años antes de su fallecimiento:

\begin{abstract}
Los más interesantes grupos aborígenes poco conocidos son los que se encuentran en el Perú, de los cuales el comisionado especial [...], el alférez de marina W. E. Safford, acaba de regresar con una maravillosa colección de trajes y curiosidades de todo tipo. Sin embargo, también ha obtenido muchas fotografías de tipos nativos, no con poca dificultad, el fotógrafo fue tan severamente herido en el costado por un guerrero que arrojó su lanza a la cámara, que se le tuvo que quitar una parte de una de sus costillas y probablemente muera. (The New York Sun, 5 de junio de 1892) ${ }^{16}$
\end{abstract}

12 Kroehle no aparece anotado en los registros de matrículas de contribuyentes elaborados por la Municipalidad de Lima en la década de 1890. Es probable que se dedicara a la actividad fotográfica "a puertas cerradas", pues se conocen fotos de salón con su sello. Ello explica el porqué debió ofrecer sus fotografías de actualidades limeñas a través de casas comerciales de la ciudad. El hecho de no abrir un estudio al público en general puede deberse a la falta de un capital significativo para iniciar una empresa de este tipo

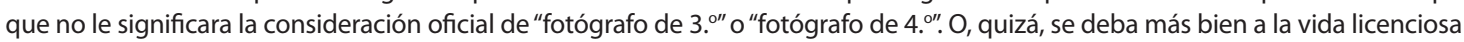
que llevó Kroehle en Lima, situación que no le permitía formalizar un negocio con estas características. Véase Libro de matrículas de patentes de la provincia de Lima (1892, 1893); Adición a la matrícula de patentes (1894). Archivo Histórico de la Municipalidad de Lima.

13 Según Pascal Riviale, es por insistencia de Ber, quien estaba deseoso de alejarlo de la comunidad alemana, que Kroehle accede a inscribirse en el consulado francés el 2 de mayo de 1893.

14 Historia similar a la fatídica expedición del prefecto del Cusco, Baltasar La Torre, a la selva de Madre de Dios, en 1873, que terminó con su fallecimiento, lo que lo convirtió en un referente de los sacrificios nacionales de la conquista interna peruana. En una fotografía de Luis Alviña, ampliada y enmarcada, probablemente para su exposición en público, aparecen los miembros de la comisión y se señalaba: "Masacrados por los huachipaires en el río Carbón. Nota. Murieron todos menos el fotógrafo". Colección JP Chaumeil.

15 Sobre la herida por el ataque de flechas en el viaje amazónico, escribieron, además de Ber, Baché (1892), Domville-Fife (1924) y Carpenter (1930).

16 Anónimo [probablemente, René Baché].“From Southern Savages. Queer costumes and curiosities collected in Peru. Fierce tribes visited by a commissioner of the Department of state. Strange Attireaud (sic) customs that are to be illustrated at the Fair (...)". 
Es un relato épico con el cual el propio fotógrafo habría colaborado. Se conoce una fotografía de la colección Pierre Marc Richard, en la que Kroehle aparece de medio cuerpo, con el torso desnudo, mordiendo un mapacho y señalando la herida abierta ${ }^{17}$.

\section{Fotografía amazónica, prensa y opinión pública}

La expedición fotográfica de Kroehle y Huebner nos confronta ante un trabajo pionero en la historia de la fotografía en el Perú. Aun cuando, para la época, se conoce la existencia de algunos registros elaborados por exploradores y etnógrafos, algunos de los cuales realizaron las primeras fotografías tipológicas de indígenas amazónicos, esta colección trasciende la obra de sus antecesores por el interés de recopilar material visual antes que tomar notas y realizar descripciones de los sujetos observados, por el trato directo que tuvieron con las poblaciones indígenas asentadas en las márgenes de los ríos recorridos - cercanía necesaria para capturar las imágenes fotográficas-, por el tipo de público que tuvo acceso al consumo de este material visual y por la prolongada exposición que alcanzaron sus imágenes en la escena nacional e internacional, llegando a ser referentes obligatorios al momento de visualizar al indígena y el territorio amazónico peruano hasta mediados del siglo $x^{18}$.

Una vez terminado el viaje, ambos fotógrafos llevaban consigo copias de los clichés de su travesía amazónica. Se calcula que la colección estuvo compuesta por más de doscientas vistas de su recorrido, con paisajes de las ciudades y poblaciones serranas y selváticas (Schoepf, 2005). Con fines didácticos, podemos dividir esta colección de imágenes en tres series. La primera cuenta con el material más abundante, originado en su paso por la cordillera en el departamento de Pasco, en sus cortas estancias en la zona del Chuchurras (cuenca del Palcazú, entre yáneshas y asháninkas), Ucayali (entre nativos kakataibos y yines), hasta su arribo a lquitos, tomadas entre mayo y noviembre de 1888. La segunda se relaciona con su estancia de medio año en el puerto de lquitos, donde abre un estudio fotográfico para el público local, entre noviembre de 1888 y junio de 1889 (se destacan vistas de la infraestructura de la ciudad y de la población mestiza local). Y la tercera está integrada por los clichés tomados durante su viaje por la selva norte con destino a la costa del departamento de La Libertad, pasando por las poblaciones colonas de Tarapoto, Lamas, Rioja, y las ciudades serranas de Chachapoyas y Cajamarca, entre junio de 1889 y mayo de 1891.

Es probable que Kroehle haya mantenido consigo gran parte de los negativos del viaje. Incluso, existe la posibilidad que George Huebner tuviera poca pericia en el manejo de la cámara y en la reproducción de los negativos, por lo que contratase a Kroehle para aprender de él durante la expedición ${ }^{19}$. El caso es que al poco tiempo de su retorno a Lima, el alsaciano remite a la revista El Perú llustrado una vista de la ciudad de lquitos, que fue litografiada y publicada en junio de 1891, con la firma "Kroehle y Crempien"20.

Por su parte, a su retorno a Alemania, Georg Huebner utilizó las fotografías para acercarse al mundo académico. Entre 1892 y 1893, presentó sus materiales en diversos eventos de la Sociedad de Geografía de Dresden, exponiendo sobre su experiencia en la Amazonía, la vida de la población indígena y el negocio del jebe. Asimismo, por estos años, publicó tres artículos ilustrados en las destacadas revistas germánicas Globus y

17 Un ejemplar de este cliché fue subastado en París por la casa Baussant Lefebre en junio del 2011 (La Serna y Chaumeil, 2016).

18 Las primeras fotografías tomadas del territorio y población amazónicos peruanos datan de fines de la década de 1860. Son las imágenes generadas por la Comisión Hidrográfica del Amazonas, institución estatal peruana creada con el fin de desarrollar exploraciones a los principales afluentes del río Amazonas — Ucayali, Tambo, Pachitea y Palcazu—, las que permitiesen demostrar su navegabilidad. Entre el personal auxiliar que la conformaba, se incluyó a un especialista en fotografía, Alberto La Rose, quien participó de la primera expedición de la comisión al Ucayali en 1868 y permaneció como miembro hasta fines de enero de 1869 (La Serna, 2012).

19 Schoepf (2005). En este sentido, la revisión de los clichés amazónicos de la serie Charles Kroehle y George Huebner integrados a los fondos del Museo Etnográfico de Hamburgo (que probablemente hayan llegado a este museo por medio de este último) nos da una serie de elementos para considerar el rol secundario de Huebner en la producción de este corpus de imágenes. En diferentes casos, la firma "Kroehle \& Huebner" muestra una notable manipulación de los créditos, sobreponiéndose a las firmas "Ch. Kroehle", "J.C. Kroehle", “C. Kroehle" y "J. Kroehle". En algunas, incluso, se ha borrado la firma de Kroehle, marcada en un lado de la fotografía para colocar, en el otro extremo, la firma conjunta.

20 Perú - Calle Belén en lquitos [litografía]. El Perú llustrado, 13 de junio de 1891. Más adelante, el 2 de abril de 1892, la revista publica otro cliché litografiado: "Indio del Ucayali, de 50 años de edad y un metro de estatura (foto. Del expedicionario Mr. Kroehle)". Es curioso reconocer que, desde estas dos tempranas remisiones, Kroehle desconoce la participación de Huebner en la expedición fotográfica. Es probable que Crempien haya sido un socio o su colaborador en los primeros meses de su estancia en Lima, luego de su tour amazónico. 
Deutsche Rundschau für Geographie uns Statistik, en las que se reproducen litográficamente algunos clichés que posteriormente fueron integrados a colecciones de museos de este país ${ }^{21}$.

Charles Kroehle no contaba con estas redes en la academia europea, lo que le significó una apuesta distinta: acercar su material fotográfico al público peruano y viajeros-científicos de paso por la ciudad de Lima, en un esfuerzo por vincularse a instituciones interesadas en los proyectos amazonistas de la época: exploradores nacionales y extranjeros, publicaciones periódicas, expediciones científicas y comisiones estatales. En este sentido, David Pretzner comentaba sobre el valor documental de su colección fotográfica de indígenas amazónicos:

Cosa digna de ver son los grupos de indios cashivos y de otros indómitos salvajes; ya sea en sus fiestas bacanales, ya sea en sus ocupaciones diarias. No se puede mirar sin espanto la fisonomía abyecta de esa gente con sus pómulos salientes e indicios carnívoros palpables. En cambio, es en extremo halagador, la colección de las vistas de esas tribus de indios semi o enteramente civilizados, entregados a sus faenas domésticas: preparando la sabrosa chicha o celebrando alguna ceremonia religiosa. (Pretzner, 1900)

Cuando, hacia finales de mayo de 1893, Teodoro Ber partió hacia París, Kroehle le encomendó un par de álbumes fotográficos a fin de que sean entregados al Ministerio de Educación Pública francés. En la carta remitida al ministro, se señala que en los dos álbumes presenta la colección completa de vistas que ha tomado de su viaje a las regiones todavía salvajes del Amazonas. Asimismo, incide en la necesidad de asegurar el reconocimiento de su autoría sobre las fotos. Pueda ser que Kroehle deseara visibilizar su trabajo etnográfico, así como conseguir algún tipo de subvención económica por su obra. En su respuesta, el ministro decidió el envío de los álbumes al Museo de Trocadero (luego pasarían al Museo de quai Branly, donde actualmente se resguardan). El interés de Kroehle de recibir algún tipo de apoyo financiero por este envío nunca se concretó (Riviale y Galinon, 2014).

Hacia 1898, Kroehle se integró como fotógrafo a algunas importantes iniciativas editoriales. Primero, participó de la elaboración del Álbum de Lima y sus alrededores (c. 1899), impreso por la sociedad financiera La Acumulativa. El catálogo contiene alrededor de cien imágenes fotograbadas, además de anuncios publicitarios de comercios y empresas de Lima, incluyendo vistas del Callao, los balnearios de Chorrillos, Barranco y Miraflores, y el trayecto del Ferrocarril Central. Si bien en el texto que precede al álbum no se anota la participación de Kroehle, su firma aparece sobre gran parte de los fotograbados.

La impresión del álbum se realizó en los talleres de Benito Gil y los grabados fueron realizados por la casa Carlos Southwell. Según señalan algunas notas periodísticas, se esperaba imprimir doce mil reproducciones, las cuales debían ser distribuidas entre los suscriptores de La Acumulativa, para luego ponerse el resto de ejemplares en venta: "Aparte de la colección de monumentos, edificios públicos, alamedas y paseos, contiene el álbum Lima otra colección no menos numerosa de fábricas y establecimientos comerciales cuyos avisos llenan las páginas en blanco de la obra" (Álbum de Lima. El Comercio, 1899)22.

Algunas de estas fotografías de la ciudad de Lima y su hinterland fueron reproducidas en la prensa ilustrada: Lima llustrado y Monitor Popular, ambas publicaciones cercanas al gobierno pierolista ${ }^{23}$. Asimismo, desde 1898, las fotografías de Kroehle fueron utilizadas por la Dirección General de Correos, que ordenó la confección de tarjetas postales con vistas del Perú, las cuales fueron elaboradas por la editorial de Guillermo Stolte y distribuidas desde diciembre de dicho año ${ }^{24}$. Estas mismas imágenes, en su gran mayoría sin referencia de su

21 Según Daniel Schoepf (2005), Huebner sentía gran interés en validar su experiencia dentro de los espacios científicos alemanes. Es por ello que reseñó cada una de las fotografías que acompañaron sus artículos, incluyendo datos que hacían referencias específicas de cada imagen, información que fue obviada por los editores de las revistas, los cuales naturalizaron las representaciones y se limitaron a ofrecer tipologías indígenas, tal como requería el público de entonces.

22 Sobre la elaboración y distribución de este álbum fotográfico realizado por La Acumulativa, véase Anónimo. (6 de febrero de 1900). Álbum de Lima. El Comercio.

23 Algunos de estos clichés fueron portadas de Lima llustrado: "Lima - Parques de la Exposición: Entrada al parque Colón - Antigua Avenida al Palacio - La laguna principal. Pabellón del Presidente - kiosko de las Palmeras - Laguna para patos". Lima llustrado, Año 2, n. ${ }^{\circ}$ 17, 22 febrero de 1900; "Chorrillos - Calle de Lima y estatua de D. Ramón Castilla". Lima llustrado, Año 2, n. 18 , 1 marzo 1900; "Lima- Hospital 2 de mayo". Lima llustrado, Año 2, n. ${ }^{\circ} 28,15$ de mayo de 1900.

24 La elaboración de cien mil ejemplares de estas tarjetas con vistas del interior de la República fue autorizada por R. S. del 9 de septiembre de 1898. Asimismo, a los pocos años de su muerte, las fotografías de Kroehle, tanto con motivos limeños como del interior del país, fueron convertidas en tarjetas postales e integradas en colecciones por diferentes editores limeños y extranjeros. 
autoría, fueron también comercializadas en impresiones de papel albúmina a viajeros, diplomáticos y científicos extranjeros a su paso por la capital.

Asimismo, la comercialización de sus fotografías del interior permitió que Kroehle se acercara a la clase política limeña que, a fines del siglo xix, aspiraba a la nacionalización de los territorios y poblaciones amazónicas. Por ejemplo, el 16 de noviembre de 1892, el explorador y militar Samuel Palacios realizó una exposición en la Sociedad Geográfica de Lima sobre sus estudios geográficos y estadísticos de la región amazónica. Días antes, la prensa limeña comentaba que se había acondicionado una sala de la sociedad para la proyección amplificada de vistas fotográficas, especialmente seleccionadas por Samuel Palacios. Fueron alrededor de cien vistas fotográficas, todas reproducciones de la serie de Kroehle \& Huebner (El Comercio, 11 de noviembre de 1892, p. 2).

Este mismo año, la comisión de antigüedades, formada por la Municipalidad de Lima con motivo de la Exposición Nacional 1892, informaba al alcalde acerca de la reciente adquisición de dos vistas fotográficas de la fortaleza de Kuélap (Muñiz, 29 de diciembre de 1892). Estas corresponden a la serie de Kroehle \& Huebner, tomadas durante su ascenso a Chachapoyas, a inicios de 1891 ["Vista frontal de la entrada (n.o 147)" y "Vista posterior de la fortaleza de Kuélap (n.o 148)"]. Sobre la muestra fotográfica, reseñaba la prensa limeña:

Se encuentra después un aparato que contiene vistas fotográficas de distintas ruinas de Ollantaitambo, Cuzco, Pachacamac, etc. (...) Pero la mejor pieza en este género es una de la piedra en facsímil de una fortaleza antigua. Esta sola pieza de algún valor relativo es una de las mejores de la colección municipal. (El Comercio, 10 de diciembre de 1892, pp. 1-4) ${ }^{25}$

Sus vinculaciones políticas evidencian una cercanía al pierolismo, relación compleja que aún no ha sido debidamente esclarecida. En marzo de 1895, aparecen en la prensa limeña anuncios de Kroehle, como corresponsal de la South American Photo Art. Co., ofreciendo al público imágenes de la revolución que sacó del poder al presidente Andrés A. Cáceres ${ }^{26}$. La proximidad a algunos miembros del Partido Demócrata, en el gobierno desde entonces, le habría facilitado su incorporación como fotógrafo en algunas iniciativas editoriales, como el Álbum Lima y sus alrededores, anteriormente señalado y, más adelante, ser parte de la más importante iniciativa de publicidad visual desarrollada por el Estado peruano en el siglo xix, la elaboración de un álbum fotográfico con imágenes de los diferentes departamentos del país, que debía ser exhibido en París, durante la Exposición Universal de 1900.

\section{El álbum República peruana 1900}

Hacia enero de 1899, la Dirección de Fomento resolvió la elaboración de un álbum sobre las diversas regiones, recursos e industrias el Perú, que debía incorporar una "colección completa de vistas de la Vía Central del Perú, desde el Callao hasta Iquitos", con la finalidad de ser remitido al pabellón peruano en la Exposición Universal de París de 1900 (Garland, 1900)27. Para materializar esta iniciativa, en enero de 1899, la Dirección de Fomento contrató a Eugenio Cummins (Capelo, 29 de marzo de 1899). El contratista, a su vez, tomó los servicios del fotógrafo Guillermo Lobatón, quien entre abril y mayo de 1899, recorrió Arequipa, Tacna y Moquegua, pasando en agosto al Cusco, donde fotografió diversos escenarios arquitectónicos y arqueológicos (La Serna y Chaumeil, 2016). Según David Pretzner, a finales de 1898, Kroehle realizó su "última excursión", recorriendo la costa norte (desde Trujillo hasta Zorritos y Cajamarca) y la región minera del departamento de Pasco con el fin de "tomar las vistas del sin fin número de minas que existen en esos lugares y de mandarlas a la Exposición de Paris, donde, en efecto, produjeron la más favorable impresión de la riqueza mineral del país" (Pretzner, 1900). Kroehle, además, ofreció las fotografías amazónicas tomadas junto con George Huebner entre 1888 y 1891. Posteriormente, todas estas imágenes fueron entregadas

25 El legado de Leonardo Villar, presidente de la Comisión de Arqueología y Antropología de la Exposición de 1892, incluye una serie de fotografías con motivos amazónicos adquirida a Kroehle durante su estancia en Lima.

26 Hacia marzo de 1895, Carlos Kroehle sale de Lima y se dirige a Cieneguilla, donde los revolucionarios tenían su cuartel general. En esta localidad, fotografió a los cabecillas de la insurrección. Una vez consolidada la asonada y depuesto el gobierno de Cáceres, la fotografía de los líderes rebeldes fue expendida en la casa comercial J. Newman, según se anuncia en la prensa en los días siguientes: "Piérola, Pauli, Durand, Oré, Collazos, en Cieneguilla por Carlos Kroehle para The South American Photo Art Co. / En venta únicamente donde J. Newton, Lima y Callao [...]" [publicidad] El Comercio, 25 de marzo de 1895.

27 Existen dos ejemplares inéditos de esta colección. El primero, en la Biblioteca Nacional del Perú y el otro en el Instituto Raúl Porras Barrenechea (Universidad Nacional Mayor de San Marcos). 
a Fernando Garreaud, quien se encargaría de la edición y encuadernación del álbum República peruana $1900^{28}$.

El álbum está compuesto por cerca de 490 fotografías impresas en papel albúmina. De las 44 fotografías amazónicas que se incluyen, 41 son reseñadas en la serie "Camino al Pichis", aunque algunas de estas imágenes corresponden a otras regiones selváticas - Chachapoyas, Tarapoto, Moyobamba, Lamas y Puerto Jaén en el Marañón-, y otras tres son de la ciudad de lquitos — prefectura y cuartel, calle Belén y vista del puerto-, todas ellas pertenecientes a la colección de Kroehle \& Huebner. Asimismo, algunas de las fotografías de la Vía del Pichis incluidas en este álbum fueron anteriormente publicadas por Federico Remy (1898) y reproducidas en las revistas Monitor Popular y Lima llustrado ${ }^{29}$.

Las imágenes incluidas en el álbum República peruana 1900 aparecen con el sello de la Casa Garreaud; en algunos casos, con la marca sobrepuesta en la firma del fotógrafo Kroehle ${ }^{30}$. En un anuncio de prensa de 1900, la casa Garreaud ofrecía al público "la colección más completa de vistas del Perú (...)", adjudicándosele desde entonces la autoría de las imágenes integradas al álbum: "de la bondad de los trabajos que ejecuta responde la magnífica colección de vistas del Perú que personalmente ha sacado" (La Serna y Chaumeil, 2016). Desconociéndose la autoría de los autores, a los pocos años, estas mismas fotografías fueron incorporadas en colecciones de postales del Perú, editadas, entre otros, por Eduardo Polack, Luis Sablich, Guillermo Stolte y la Librería e Imprenta Gil.

\section{A manera de conclusión}

La fotografía de finales del siglo xIx se enmarca dentro del proceso de reconstrucción nacional que acontece en el país tras la derrota en la Guerra del Pacífico. Expresa el encumbramiento de los discursos regeneracionista y positivista dentro de la intelectualidad y la política estatal peruanas. En este contexto, la región amazónica alcanzó una especial significación dentro de los proyectos políticos y los sueños del progreso material. Para ello, el positivismo, como soporte ideológico del orden y progreso, ofreció a las élites la posibilidad de imaginar el Perú como una nación moderna, emulando los cambios y transformaciones alcanzados por los países europeos y Norteamérica.

Entre estos planteamientos, la cámara fotográfica cumplió un rol destacado, como respuesta tecnológica y objetiva a la necesidad de conocer y desarrollar mecanismos efectivos de control del territorio, al tiempo que permitía divulgar entre la opinión pública urbana los avances en los proyectos de dominio del espacio interior. Así, al tiempo que el Perú moderno iba dominando y haciendo suyo el territorio para el aprovechamiento de los recursos y la ampliación del comercio, crecía la inquietud acerca del destino de las poblaciones indígenas amazónicas y la posibilidad de hacer de aquellos indios indómitos e infieles piezas fundamentales en la futura vertebración social y económica de los bosques amazónicos al resto del país. En esto, radica la importancia de la fotografía como herramienta fundamental en la tarea de clasificación y ordenamiento visual de una población y un territorio que lentamente se iban

abriendo camino a la civilización; es decir a la vida moral y material (...) [donde] millares de hermanos nuestros que, más tarde, serán también nuestros conciudadanos, porque sus ojos se habrán abierto ante la luz esplendorosa de la fe y el progreso. (EI Perú Ilustrado, 24 de marzo de 1888, p. 2)

La agitada vida del fotógrafo alsaciano J. Charles Kroehle, su aventura amazónica junto con Georg Huebner y su estancia prolongada en la ciudad de Lima,

28 Al mismo tiempo, los editores de Monitor Popular, revista progubernamental pierolista, publicaban una nota solicitando a sus lectores la remisión de materiales fotográficos: "Solicitamos a nuestros agentes y suscriptores de provincia y a cuantos se interesen por el bien del país se sirvan [enviar] fotografías o dibujos que den alguna idea de las localidades respectivas. Los datos que pedimos (...) los utilizaremos para completar los que hemos reunido para el Álbum Gráfico del Perú, que estamos preparando, con el objetivo de llamar una vez más la atención de propios y extraños a los elementos que poseemos y a las facilidades que ofrece nuestra patria como centro de trabajo" (Monitor Popular, 25 de febrero de 1899).

29 Remy fue comisionado por la Sociedad Geográfica de Lima en 1896 para realizar fotografías de las regiones selváticas del Pichis y el Perené. También existe la posibilidad de que algunas de estas vistas de la vía del Pichis correspondan a las fotografías que Juan S. Villalta tomó por encargo de Joaquín Capelo, entonces Comisionado Especial del Gobierno en el departamento de Loreto, hacia diciembre de 1899 (La Serna y Chaumeil, 2016).

30 Se conoce la cercanía de la familia Garreaud con el entonces presidente de la República, Nicolás de Piérola (Majluf y Wuffarden 2001). Aunque diversos investigadores han asumido la autoría de Fernando Garreaud de los trabajos fotográficos incluidos en el álbum, su función se limitó a la edición y encuadernado de los materiales fotográficos para su exhibición. Hasta finales de 1899, Garreaud había trabajado en la Casa Courret \& Cía. Fue entonces que estableció su propio estudio, la Fotografía Francesa, en la calle La Merced n. ${ }^{\circ} 285$, negocio que al abrir sus puertas en junio de 1890 fue descrito por la prensa limeña como uno de los más lujosos y atractivos de la ciudad (La Serna y Chaumeil, 2016). 
dedicándose a la comercialización de sus clichés amazónicos, al tiempo que buscaba la manera de integrar su producción visual dentro de espacios de divulgación mayor, sean nacionales o extranjeros, expresa también el encuentro de diversas iniciativas de carácter amazonista que confluyeron en el Perú en las postrimerías del siglo xIx.

Por último, la elaboración del álbum República peruana 1900 marca el esfuerzo más destacado llevado a cabo por el Estado peruano a fin de consolidar su propia narrativa visual sobre la Amazonía, frente a la urgente necesidad de integrar al territorio y población del interior dentro de los imaginarios nacionales construidos y proyectados desde la perspectiva modernizadora y regeneracionista de la élite intelectual y política limeña, que terminó consolidándose en el control del Estado en las primeras décadas del siglo xx.

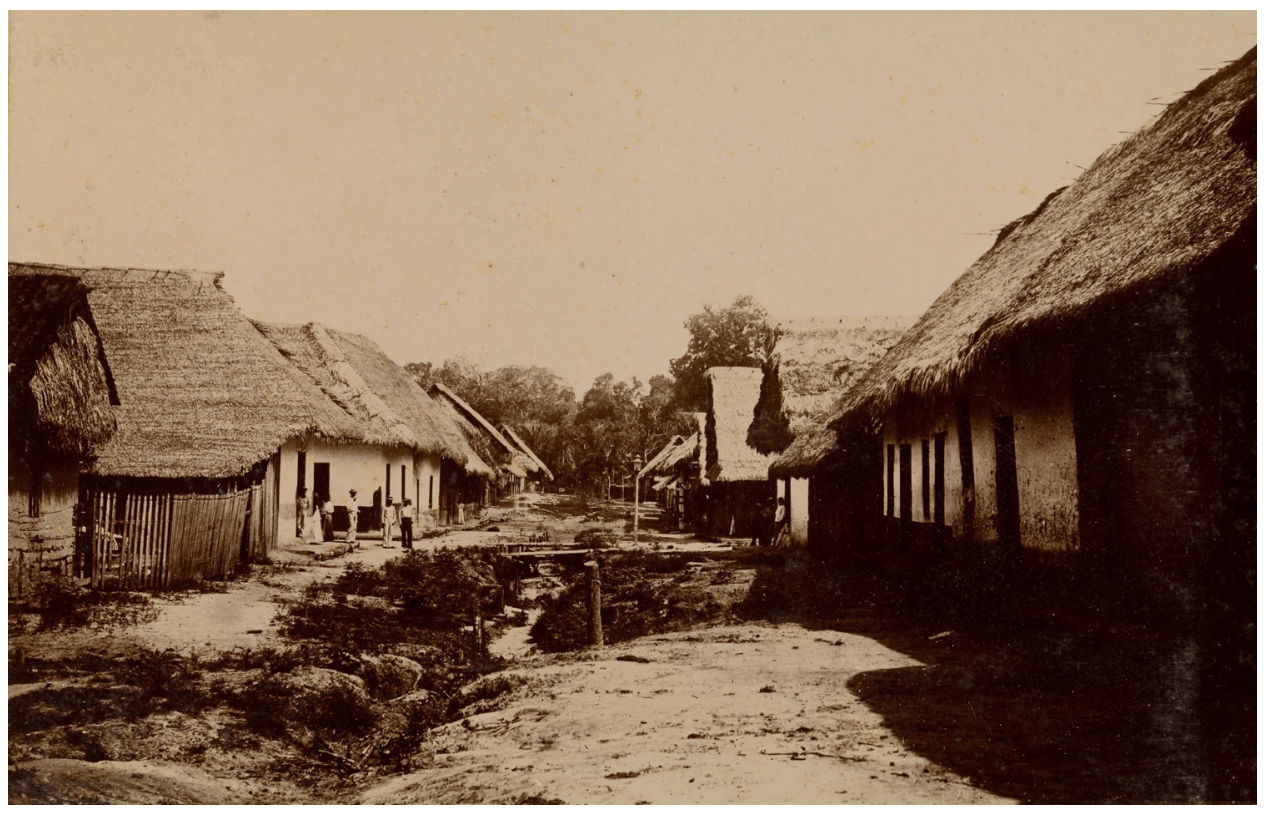

Figura 1: Calle Belén en Iquitos. Fotografía de Kroehle \& Huebner, entre noviembre de 1888 y junio de 1889. Tomada del álbum República peruana 1900.

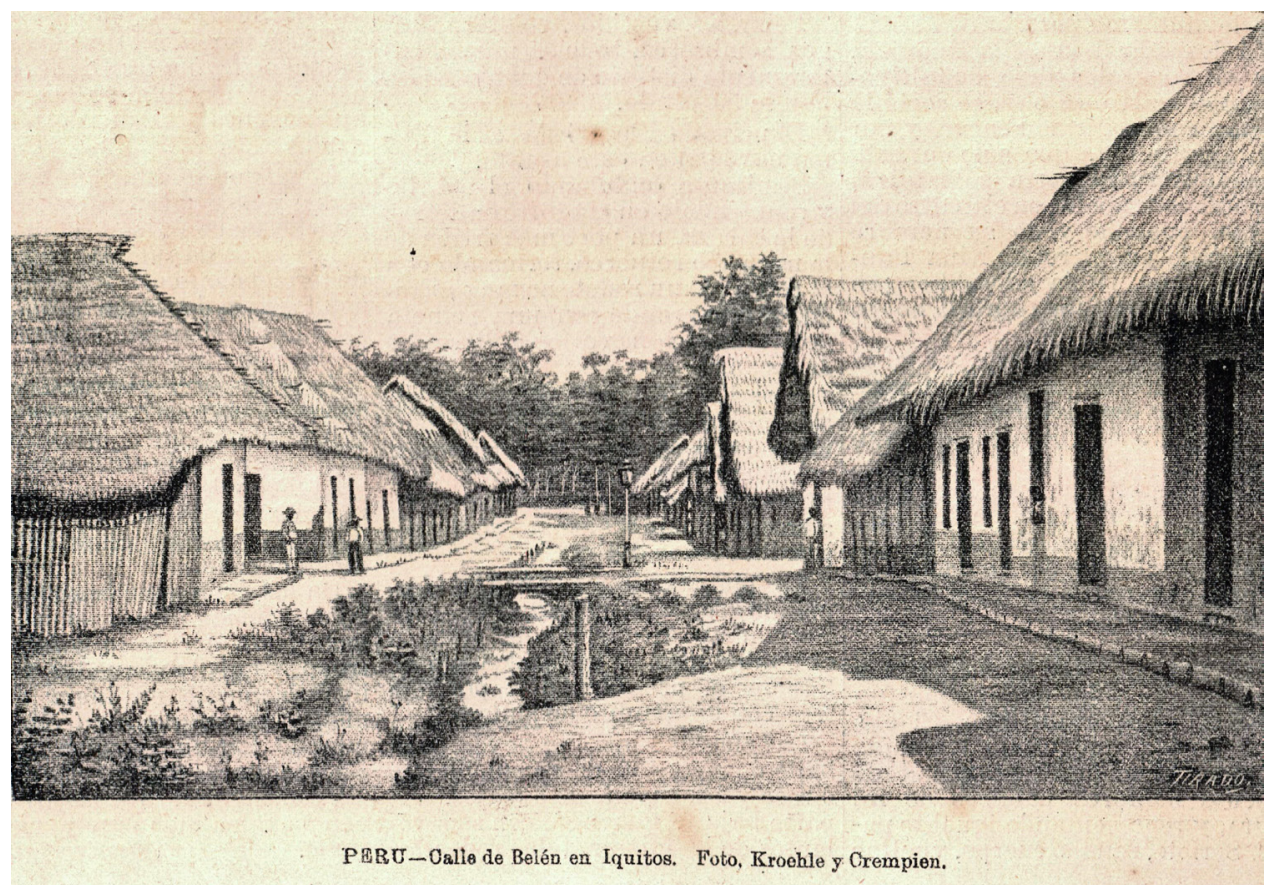

Figura 2: La misma vista litografiada publicada en El Perú Ilustrado (13 de junio de 1891), adjudicada a Kroehle \& Crempien. 


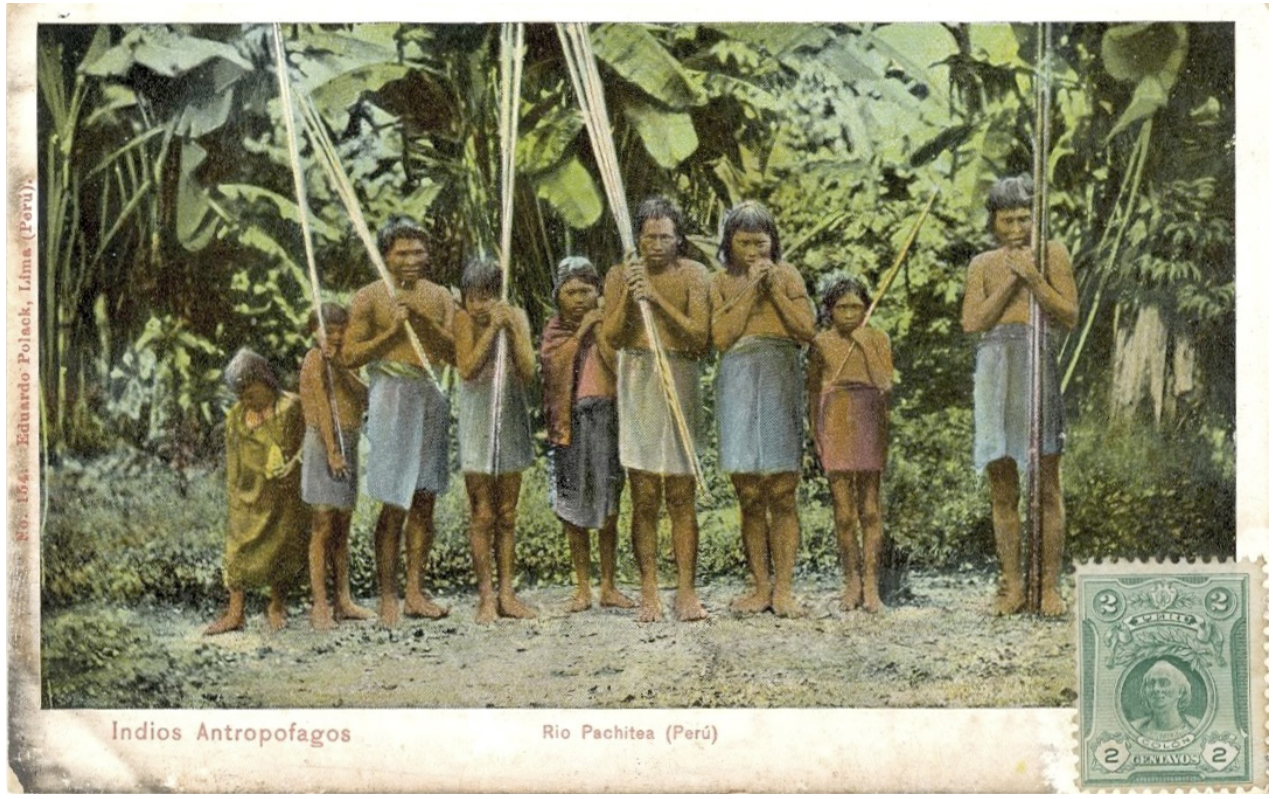

Figura 3:"Indiens cachives antropophages Suncar-yacu flauve Pachitea" Fotografía de Kroehe \& Huebner, hacia 1888. Tomado del álbum ofrecido por Kroehle al ministro de Instrucción Pública francés. Museo de quai Branly.

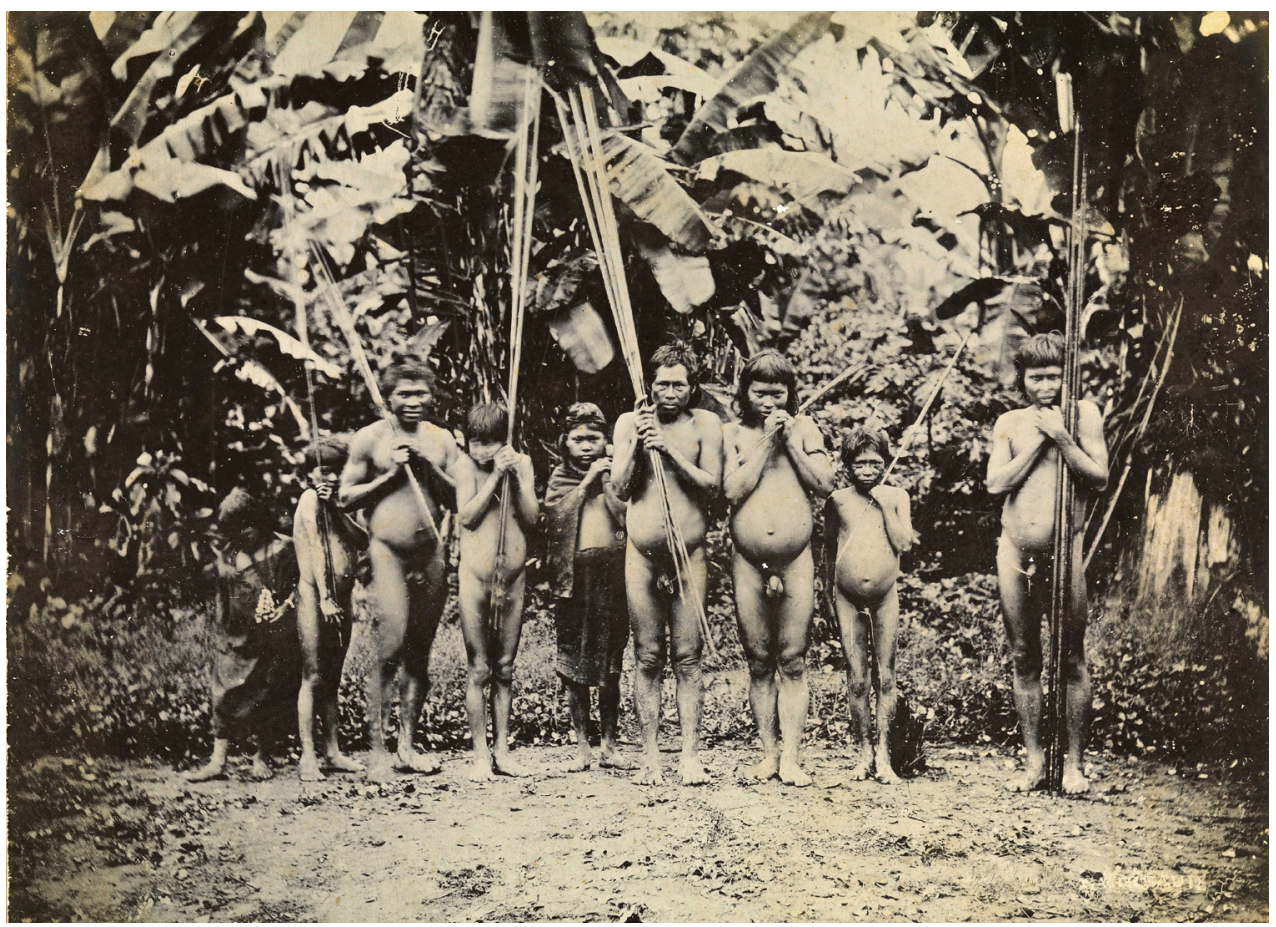

Figura 4: La misma imagen, en formato de tarjeta postal coloreada, editada por Eduardo Polack, a inicios de 1900. Colección J. C. La Serna. 


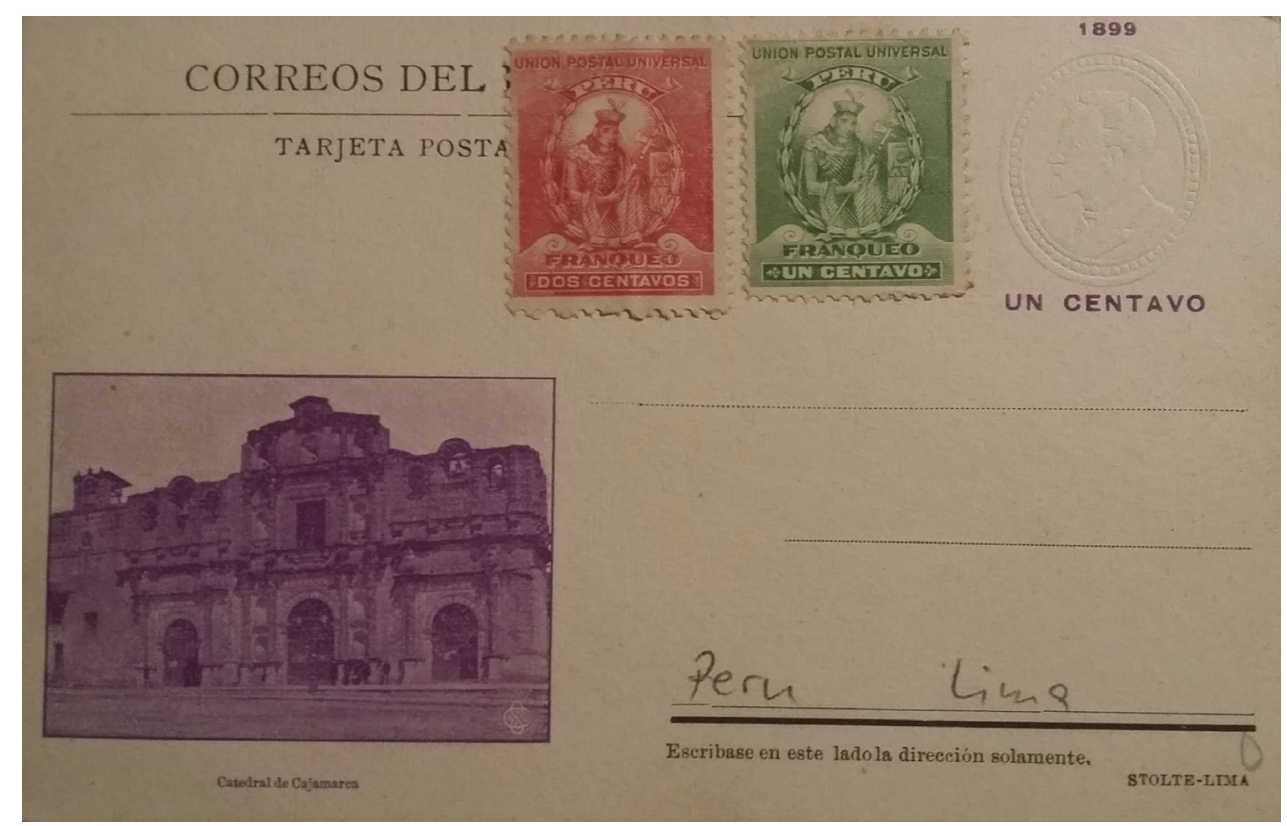

Figura 5: Reverso de una postal ilustrada, editada por Guillermo Stolte en la serie "Recuerdos de Lima", fechada en 1899. Incluye grabados, posterior y frontal, basados en fotografías de Kroehle. En la imagen, Catedral de Cajamarca, tomada hacia febrero de 1891. Colección Percy Reinoso (París).

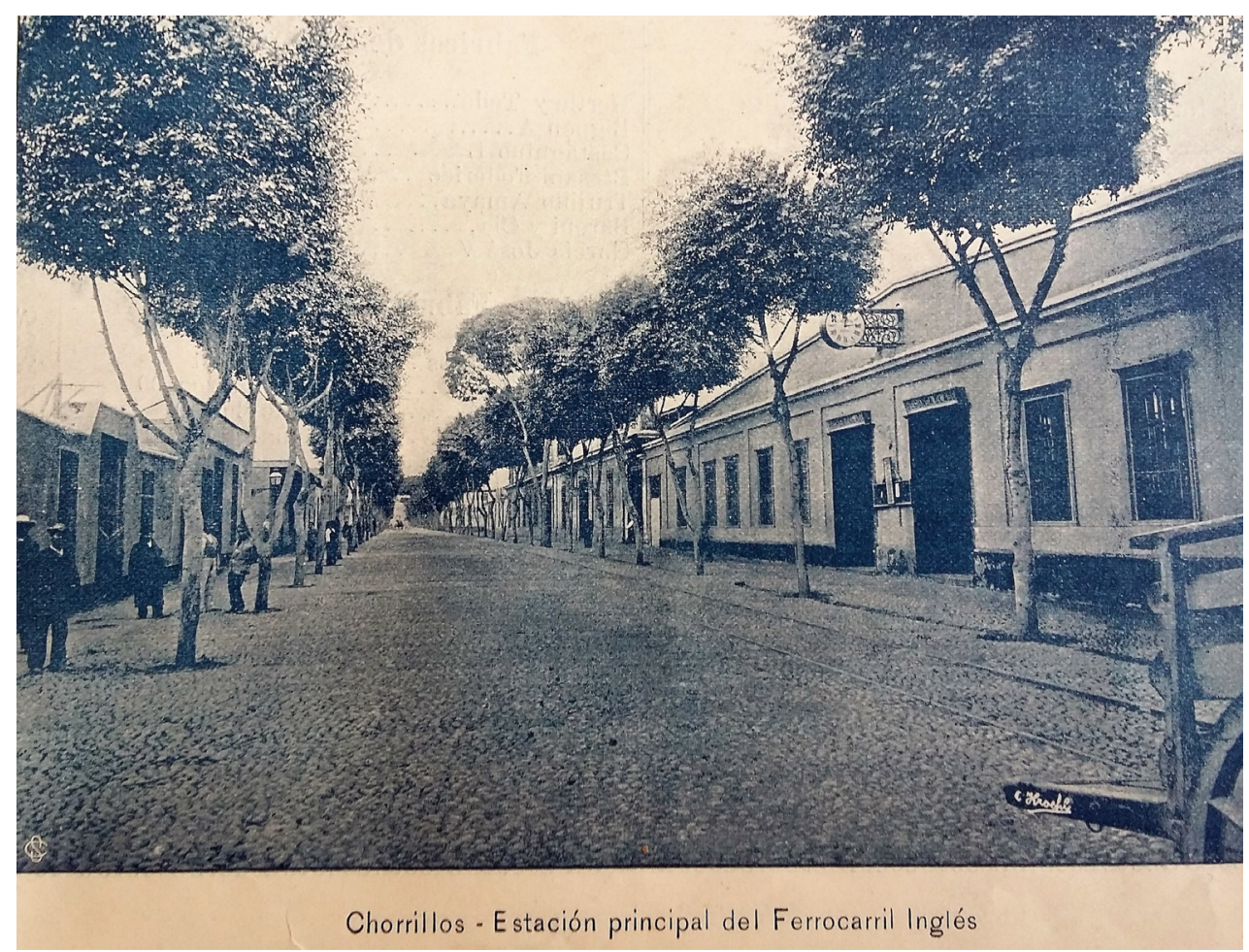

Figura 6: Chorrillos - Estación principal del ferrocarril inglés. Fotograbado a partir de un cliché de Carlos Kroehle. Tomado del álbum Lima y sus alrededores (c. 1899). 


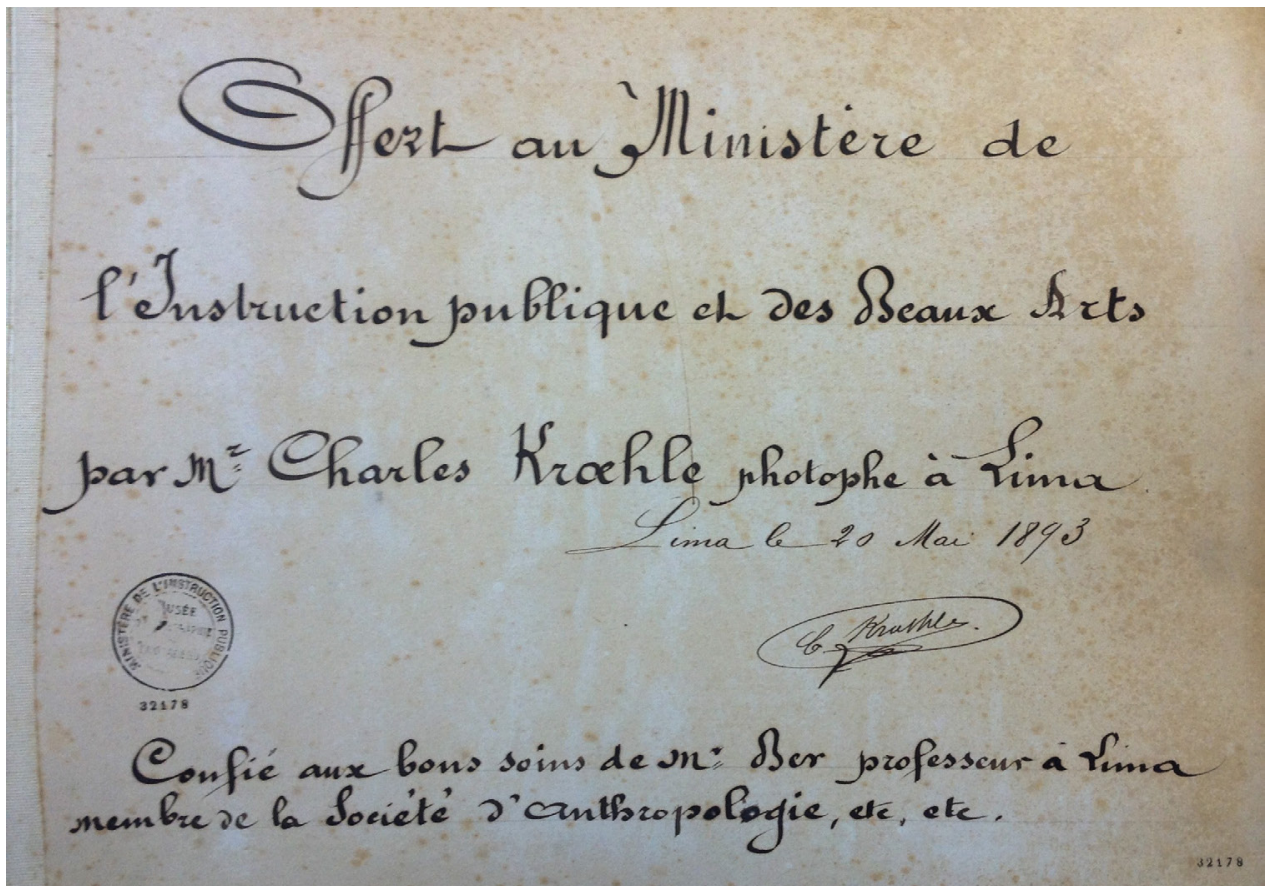

Figura 7: Carátula del álbum fotográfico editado por Charles Kroehle, remitido al ministro de Instrucción Pública y Bellas Artes por intermedio de Teodoro Ber. Firmado por Kroehle en Lima, el 20 de mayo de 1893. Iconoteca del Museo de quai Branly.

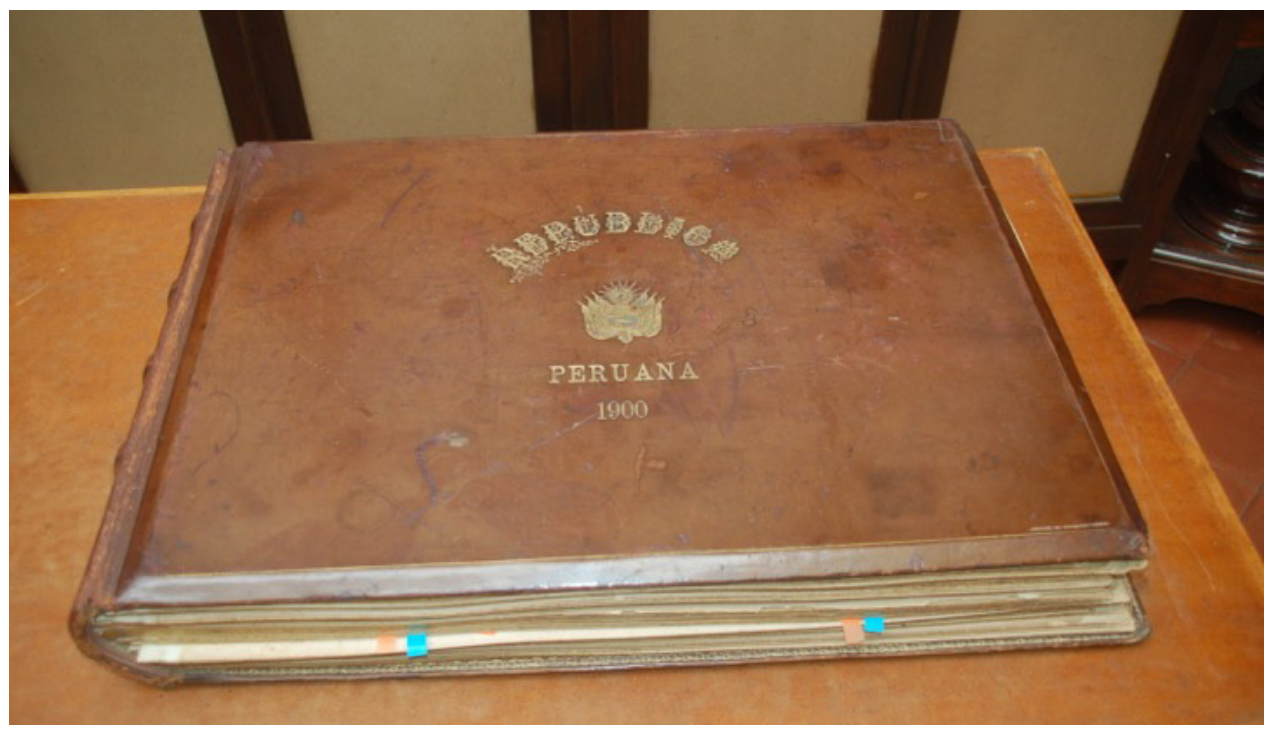

Figura 8: Portada del álbum República peruana 1900, editado por Fernando Garreaud para su exhibición en la Exposición Universal de París de 1900. Fotografía cortesía del Instituto Porras Barrenechea.

\footnotetext{
Fuentes

Álbum de Lima. (23 de julio de 1899). El Comercio.

Capelo, J. (29 de marzo de 1899). Circular del Director de Fomento, J. Capelo, al Subprefecto de Puno. Archivo Histórico Regional de Puno.

Exposición Nacional de 1892. (10 de diciembre de 1892). El Comercio [segunda edición], pp. 1-4.

Fry, C. (1889). La gran región de los bosques o ríos peruanos navegables: Urubamba, Ucayali, Amazonas, Pachitea y Palcazú. Lima: Ed. Gil [1. ${ }^{a}$ parte,] / Imp. del Universo [2. ${ }^{a}$ parte].

Nuestros grabados. (24 de marzo de 1888). El Perú llustrado, p. 2.
} 


\section{Referencias}

Along the Perené and the Amazon. (1930). S. a. Nueva York: Doubleday Doran \& Co.

Carpenter, F. G. (1900). South America: social, industrial and political. Nueva York: The Saalfield Pub. Co.

Chaumell, J.-P. Charles Kroehle, photographe de l'impossible. En 40 ans dan les Andes. L'itinearire oublié de Théodore Ber (1820-1900) (pp. 105-108). París: Musée Champollion.

Domville-Fife, CH. (1924). Among wild tribes of the Amazon. An account of exploration \& adventure. Londres: Seeley, Servie \& Co.

FLORES, R. (2011). Etnografía visual y colonización cauchera. En G. Cánepa (Ed.), Imaginación visual y cultura en el Perú (pp. 197-219). Lima: Pontificia Universidad Católica del Perú.

Garland, A. (2 de junio de 1900). El Perú en la Exposición de 1900. El Comercio.

Garreaud, F. (Ed.). (1900). República peruana 1900 [Presentación en la Exposición Internacional de París] (inédito, manuscrito en el Instituto Porras Barrenechea, Lima).

Gobé, M. (mayo del 2015). Charles Kroehle (1862-1900). Photographe au Pérou a la fin du XIXéme siécle. Memoire d'etude. París: Ecole du Louvre.

KoHL, F. S. (2015). Eastern Peru - The region and its people (1888-1891), documented by Kroehle \& Huebner. En G. Wolff (Ed.), Explorers and entrepreneurs behind the camera. The histories behind the pictures and photographs from the image archive of the Ibero-American Institut (pp. 76-85). Berlín: Instituto Ibero-Americano de Berlín.

LA-SERNA, J.-C. (2011). Visiones de progreso, otredad y fronteras internas en la construcción de la Amazonía peruana. Una aproximación a los discursos visuales sobre la "montaña" a fines del siglo xIx. En Cánepa, G. (Ed.) Imaginación visual y cultura en el Perú (pp. 221-246). Lima: Pontificia Universidad Católica del Perú.

LA-SERNA, J.-C. (2012). Los tempranos usos oficiales de la imagen del bosque. Exploración, fotografía y Estado en la montaña peruana (1868-1918). Cuadernos de Investigación Universitaria, (1), 131-154.

LA-SERNA, J.-C. (2013). La domesticación visual de la montaña. Imágenes del territorio y población amazónica proyectadas por El Perú llustrado (1887-18922). Nueva Coronica. Revista de la Escuela de Historia de la Universidad Nacional Mayor de San Marcos, 1(2), 377-394.

LA-SERNA, J.-C. (diciembre del 2015). The forest as cliché: otherness, progress, and internal frontiers in early photography from the Amazon. American Anthropologist, 117(4), 795-812.

LA-SERnA, J.-C., y ChAUmeIL, J.-P. (2016) El bosque ilustrado. Diccionario histórico de la fotografía amazónica peruana (1868-1950). Lima: Centro Amazónico de Antropología y Aplicación Práctica, Instituto Francés de Estudios Andinos, Centre National de la Recherche Scientifique, Pontificia Universidad Católica del Perú.

Majluf, N., y Wuffarden, L.-E. (Eds.). (2001). La recuperación de la memoria. El primer siglo de fotografía: Perú 1842-1942. Lima: Museo de Arte de Lima, Fundación Telefónica.

Moss, M. (1909). A trip into the interior of Peru. Lima: Ed. Ch. Southwell.

Muñı, M. (29 de diciembre de 1892). Oficio de M. M. al alcalde de Lima. Fondo Obras Públicas, Archivo Histórico de la Municipalidad de Lima.

Poole, D. (2000). Visión, raza y modernidad. Una economía visual del mundo andino en imágenes. Lima: SUR.

Pretzner, D. (11 de diciembre de 1900). Karl Kroehle. El Comercio.

Remy, F. (1898). Apuntes sobre el clima y la flora de la región del Pichis. Lima: Imp. del Monitor Popular. 
Riviale, P., y Galinon, CH. (2014). 40 ans dans les Andes. L'itinéraire oublié de Théodore Ber (1820-1900). Figeac: Musée Champollion.

SCHOEPF, D. (2005). George Huebner 1862-1935: Um fotógrafo em Manaus. San Pablo: Metalivros.

Sociedad GeOgráfiCA. (11 de noviembre de 1892). El Comercio [segunda edición], p. 2.

TAGG, J. (2005). El peso de la representación. Ensayos sobre fotografías e historias. Barcelona: Ed. Gustavo Gili S. A.

VAlentin, A. (2009). Os "Indianer" na fotografia amazonica de George Huebner (1885-1910) (tesis de doctorado en Historia Social). Universidad Federal de Río de Janeiro.

Von BAYERN, T. (1908). Reisestudien aus dem Westlichen Südamerika. Berlín: Dietrich Reimer. 